\title{
https://doi.org/10.52240/1857-2367.2020.2(21).27 SPECII DE DIGITALIS L. ÎN GRĂDINA BOTANICĂ NAȚIONALĂ - ASPECTE DE CONSERVARE ȘI CULTIVARE EX-SITU
}

\author{
Mihaela MUNTEANU, Ștefan BELOUS, Tatiana IZVERSCAIA, \\ Veaceslav GHENDOV, Nina CIOCARLAN \\ Grădina Botanică Națională (Institut) "Al. Ciubotaru”, \\ Chișinău, Republica Moldova
}

\begin{abstract}
The paper presents scientific data on 4 species of the genus Digitalis L. (D. lanata Ehrh., D. grandiflora Mill., D. purpurea L. and $D$. ferruginea L.). The bibliographic study was performed regarding the multiplication methods, biological aspects and the conservation strategies of rare species. Phenological observations and biometric measurements were performed and the behavior of the plants under cultivation conditions was monitored. The preliminary results demonstrated the perspective of ex-situ cultivation and conservation.
\end{abstract}

Key words: toxic plants, Digitalis, therapeutic effects, multiplication, cultivation, ex-situ conservation. 
Genul Digitalis L. (familia Scrophulariaceae) cuprinde circa 30 de specii erbacee anuale, bienale sau perene, originare din Europa, Asia Centrală și de Vest. Speciile din genul Digitalis L. și derivatele acestora sunt importante din punct de vedere terapeutic fiind utilizate în managementul insuficienței cardiace și a afecțiunilor cardiace asociate. Sunt specii toxice și se administrează doar sub supraveghere medicală. Unele sunt specii rare și/sau ameninţate cu dispariţia, fiind necesară multiplicarea şi conservarea lor.

Studiul se referă la 4 specii de Digitalis L., două specii autohtone (D. lanata și $D$. grandiflora) și două specii alohtone (D. ferruginea, obținut prin schimbul internațional de semințe cu Grădina Botanică din Nantes, Franța în anul 2009 și $D$. purpurea, provenit din Grădina Botanică din Duisburg, Germania în a. 2004).

Specia D. lanata (Figura 1) este specie rară în flora republicii, inclusă în Cartea Roșie a Republicii Moldova (ed. a III-a) [1], cu statut de specie critic periclitată. Specia D. grandiflora (Figura 2) este întâlnită rar în flora spontană. Distrugerea habitatelor naturale, colectarea plantelor de către populaţie sunt unii din factorii care periclitează existenţa speciei. Cercetările au cuprins studii de biologie, ecologie și fitochimie, aspecte de înmulţire, tehnologii primare de cultivare şi elaborarea măsurilor de conservare pentru speciile rare. La prima etapă s-a efectuat studiul bibliografic referitor gradului de raritate, metodelor de multiplicare şi strategiilor de conservare a speciilor rare investigate. Multiplicarea plantelor s-a efectuat conform metodelor tradiţionale utilizate în laborator. A fost efectuat studiul calitatăţii seminţelor, particularităţile înmulţirii generative, determinat coeficientul de germinare a semințelor în dependență de durata de păstrare. S-au efectuat observaţii fenologice şi măsurări biometrice [2] și monitorizat comportamentul plantelor în condiții de cultură.

Rezultatele primelor cercetări au demonstrat faptul, că în condiţii de cultură speciile studiate realizează întreg programul ontogenetic, fapt care demonstrează plasticitatea lor ecologică, înaltul potenţial adaptiv, precum şi perspectiva conservării ex-situ a acestor plante. Speciile alohtone D. purpurea (Figura 3) și D. ferruginea (Figura 4) s-au adaptat cu succes în condițiile de climă și sol ale țării noastre. În prima perioadă de vegetație ele prezintă o creștere excelentă cu expansiune vegetativă mare, formând rozete din 8-20 frunze. Plantele înfloresc abundent în a doua perioadă de vegetație. Multiplicarea plantelor prin diverse metode va permite obţinerea materialului săditor şi semincer suficient

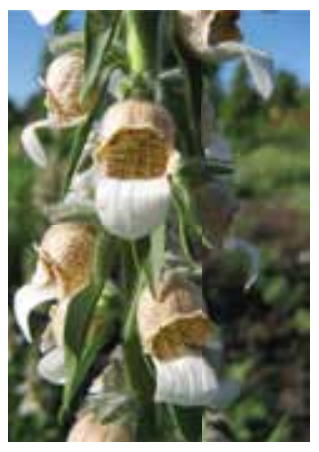

Figura 1. Digitalis lanata

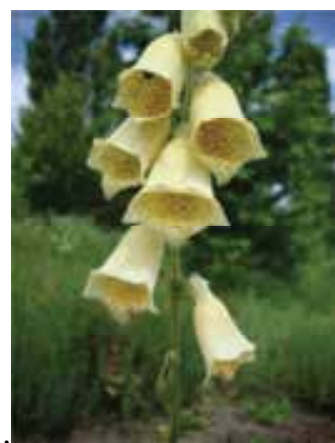

Figura 2. Digitalis grandiflora

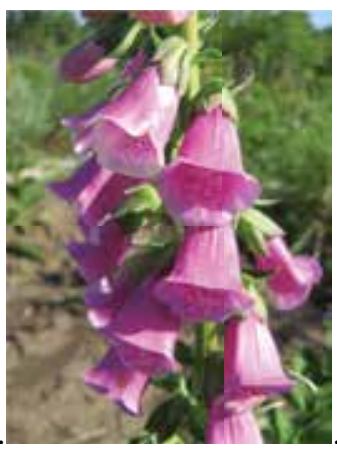

Figura 3. Digitalis purpurea

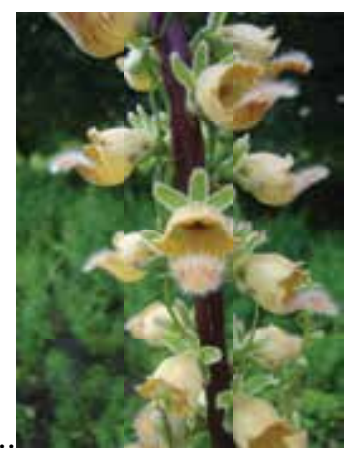

Figura 4. Digitalis ferruginea 
pentru reintroducerea speciilor rare (D. lanata) în condiţii naturale de creştere fiind una din căile de menţinere a resurselor lor genetice.

Cercetările au fost realizate cu suportul ANCD în cadrul proiectului „Cercetarea și conservarea florei vasculare și macromicobiotei din Republica Moldova”, cifrul 20.80009.7007.22 (contract de finanțare $\mathrm{Nr}$. 71/PS/2020).

\section{BIBLIOGRAFIE}

1. Izverscaia T., Ciocârlan N. Digitalis lanata Ehrh. In: The Red Book of the Republic of Moldova, $3^{\text {rd }}$ ed. 2015, Chişinău: Ştiinţa, p. 108.

2. Майсурадзе Н. И., Черкасов О.А., Тихонова В. Л. Методика исследований при интродукции лекарственных растений //ЦБНТИ. Сер. Лекарств. растениеводство. М., 1984, №3, 33 стр. 